\title{
Faktor Penunjang Pertunjukan Musik: Input, Proses, dan Output
}

\author{
Ovan Bagus Jatmika \\ Progam Studi Musik, Fakultas Seni Pertunjukan, Institut Seni Indonesia Yogyakarta \\ Email: ovanbagusjatmika@gmail.com
}

\begin{abstract}
This research examines the supporting factors in improving the quality of musical performances. The method used is qualitative and the research data are found through library research. The author concludes that a performance is considered to have ideal conditions if it involves three elements that support each other in the process towards the end of the musical execution on the stage, namely input, process, and output. These three elements (input, process, and output) are expected to improve the quality of the performance. The intended form of quality improvement is the formation of two-way communication or dialogue between the player and the audience. The player conveys the musical content of their interpretation of the work being played, while the audience responds to the standard measure of musical, visual and gestural norms that they have / believe in.
\end{abstract}

Keywords: musical stimuli, musical emotions, learning motivation, exercise effectiveness, musical memory.

\begin{abstract}
ABSTRAK
Riset ini dimaksudkan untuk meneliti faktor-faktor penunjang dalam meningkatkan kualitas pertunjukan musik. Metode yang penulis pakai adalah kualitatif dan riset data diperoleh lewat studi pustaka. Penulis dapat menyimpulkan bahwa sebuah pertunjukan dianggap memiliki kondisi ideal jika melibatkan tiga unsur yang saling mendukung dalam proses menuju akhir eksekusi musik di atas panggung yaitu input, proses, dan output. Ketiga unsur ini (input, proses, dan output) diharapkan dapat meningkatkan kualitas pertunjukan. Bentuk peningkatan kualitas yang dimaksud adalah terbentuknya komunikasi atau dialog dua arah antara pemain dan penonton. Pemain menyampaikan konten musikal hasil interpretasinya atas karya yang dimainkan, sementara penonton memberikan respon dengan standar ukuran norma-norma musikal, visual, dan gestural yang mereka miliki/yakini.
\end{abstract}

Kata kunci: stimuli musikal, emosi musikal, motivasi belajar, efektivitas latihan, memori musikal.

\section{PENDAHULUAN}

Isu dan wacana tentang tema pertunjukan musik melibatkan banyak diskusi dari berbagai perspektif. Apa yang coba penulis uraiakan pada tulisan ini adalah wacana pertunjukan musik dari sudut pandang kualitasnya. Memang terkesan terburu-buru jika langsung mengukur sebuah kualitas pertunjukan dari parameter tertentu karena ukuran kualitas sebuah pertunjukan melibatkan banyak parameter ukuran yang sebagiannya sarat dengan aspek subjektivitas. Dalam hal ini penulis tidak akan menentukan ukuran baik buruk sebuah kualitas pertunjukan, namun yang penulis uraian adalah kondisi-kondisi (faktor penunjang) yang dianggap ideal dalam sebuah pertunjukan. Kondisi tersebut penulis bagi menjadi tiga yaitu: input, proses, dan output. Yang dimaksud input dalam hal ini adalah kondisi yang mempengaruhi individu dalam hal kecakapan musikalitas jauh sebelum 
individu bersentuhan dengan dunia musik secara formal. Proses dimaknai sebagai kondisi ketika individu sudah secara intens berlatih musik baik dalam pendidikan formal, semi, atau non-formal. Sedangkan output adalah kondisi ketika individu sudah memfokuskan aktivitas latihan bermusik dalam kebutuhannya untuk ditampilkan di depan publik. Litaratur yang penulis pakai sebagai rujukan diambil dari ranah psikologi musik dan pedagogi musik (disamping juga beberapa literatur sejarah). Sekalipun apa yang penulis uraikan dapat diaplikasikan pada berbagai jenis pertunjukan musikal, namun fokus penulis adalah pada tradisi pertunjukan Musik Barat.

\section{METODE}

Riset ini berada di bawah payung metode kualitatif. Lebih tepatnya lewat pendekatan (strategi penelitian) fenomenologis. Secara teknis, riset ini dilakukan lewat kajian literatur. Adapun literatur yang penulis gunakan sebagian besar penulis ambil dari khasanah disiplin psikologi musik dan pedagogi musik, disamping juga beberapa literatur sejarah. Analisis data penulis lakukan dengan cara mengkomparasikan data temun dari literatur yang telah dikaji. Adapun ulasannya adalah sebagai berikut.

\section{HASIL DAN PEMBAHASAN}

Aspek yang mempengaruhi individu sejak usia dini dalam hal kecakapan performance.

Ada dua aspek utama yang mempengaruhi individu dalam hal kecakapan performance, yaitu aspek genetic (nature) dan lingkungan (nurture). Dari kedua aspek tersebut, para psikolog cenderung meyakini bahwa lingkungan memiliki pengaruh yang lebih signifikan dalam membentuk kecakapan musikal. Hal ini didasarkan pada konsep 'normal distribution' yang, jika kita menerimanya, maka sebagian besar orang (sekitar $95 \%$ populasi) mempunyai potensi yang sama terkait dengan kapasitas serta struktur fisik dan mental. Lebih jauh, lingkungan dikatakan dapat membentuk kecakapan individu dalam hal ketrampilan musikal lewat cara memunculkan kesadaran motivasi belajar dari setiap individu. Sebaliknya, jika lingkungan tidak dapat memunculkan kesadar motivasi belajar dari individu, maka kecakapan performance yang diharapkan cenderung sulit tercapai.

Aspek genetic mempengaruhi individu dalam sejumlah hal. Pertama, perkembangan fase maturational (pematangan). Misalnya, keharusan untuk bisa merangkak sebelum berjalan. Dalam hal musik tampak misalnya pada keharusan untuk melatih tangga nada dalam tempo lambat sebelum bisa memainkannya secara cepat. Kedua, keunggulan dalam hal fisik. Orang dengan postur tinggi mampu melompat lebih baik dari orang berpostur pendek. Dalam musik misalnya, orang dengan jari panjang cenderung lebih mudah memainkan interval jauh daripada orang berjari pendek. Ketiga, keunggulan dalam hal mental. Beberapa orang dapat melakukan tugas lebih cekatan dari yang lain. Dalam konteks musik misalnya, beberapa orang cenderung mempunyai 
kepekaan dalam mengidentifikasi pola musikal sehingga mampu melakukan manipulasi secara lebih kreatif dibanding yang lain.

Aspek lingkungan juga dapat mempengaruhi individu dalam sejumlah hal. Jane Davidson menyebutkan lima faktor yang dapat mempengaruhi atau membentuk kecakapan individu dalam hal ketrampilan musikal. Simpulan yang ia rumuskan tersebut didasarkan pada hasil telaahnya atas sosok musisi jazz fenomenal, John Coltrane. la melihat bahwa sekalipun Coltrane besar di jalanan dan hampir tidak pernah mendpat pendidikan formal, namun lingkungan tempat ia tinggal mampu memberikan stimuli musikal yang luar biasa dan mampu mengembangkan kemampuan musikal Coltrane kecil secara maksimal. Kelima faktor tersebut secara sistematis dikaji oleh psikolog dan diidentifikasi sebagai faktor kunci dalam mengembangkan ketrampilan musikal.

Pertama, lingkungan dapat memberikan stimuli musikal yang, sekalipun biasa, terjadi secara terus menerus. Diyakini bahwa lingkungan mempengaruhi individu bahkan sebelum kelahiran. Janin di dalam perut dapat mendengarkan musik dan pembicaraan beberapa minggu menjelang kelahiran. Secara umum dikatakan bahwa pengalaman janin sangatlah musikal. la mampu merasakan ritme dari tubuh ibu dan mendengar perubahan nada (kontur melodi) dari noise eksternal termasuk omongan dan musik. Maka, stimuli sebelum kelahiran adalah salah satu aspek terpenting dari keseluruhan pengalaman lingkungan. Bayi yang mendapatkan stimulasi yang baik pada fase ini akan memperoleh keuntungan dalam hal perkembangan kecerdasan dan musikalitas.

Kedua, lingkungan memungkinkan peluang untuk secara bebas mengeksplorasi media musik. Selama masa pertumbuhan bayi, 'motherese' (pengalaman kebersatuan bayi dengan sang ibu di fase imajiner, jika kita meminjam istilah Lacan) dan komunikasi gestural adalah dasar dari perkembangan level ketrampilan yang akan dipelajari berikutnya. Komunikasi gestural seperti tepukan tangan membantu mengembangkan sensibilitas ritme, tempo, serta dinamika.

Ketiga, lingkungan memungkinkan peluang untuk mengalami intensi emosional atau estetis dalam merespon musik. Motherese dan aktivitas gestural dikembangkan oleh bayi untuk mengkomunikasikan aspek emosional antara kedirian dan kebutuhan (needs). Dari sini, hubungan antara emosi, gestur fisik, dan makna musikal terbentuk. Interaksi yang bersifat kuasi-musikal antara ibu dan bayi pada masa pertumbuhan menggiring pada kondisi perkembangan makna musikal (yang bersifat tak disengaja) serta kompetensi dalam hal performance. Pengalaman awal musikal ini akan menjadi modal utama bagi anak untuk bisa mempunyai komitmen dalam pembelajaran musik secara lebih serius di kemudian hari. Riset menemukan bahwa anak yang mempunyai kelebihan dalam hal perkembangan kecakapan musikal cenderung mempunyai pengalaman atau keterikatan dengan bentuk-bentuk permainan atau stimuli musikal selama periode kritis dari kelahiran hingga umur dua tahun. 
Pengalaman emosional ini merupakan prasyarat untuk bisa mempunyai ikatan komitmen dalam proses belajar. Anthony Kemp mengatakan bahwa 'it is the music which attracts certain personalities to engage with it or the personalities which are shaped by music'1. Dari apa yang dikatakan Kemp, kita tidak dapat memastikan siapa mempengaruhi siapa. Namun kita dapat mengatakan bahwa keterikatan dengan pengalaman musikal mempunyai pengaruh positif terhadap aspek emosional. Eksperimen dalam domain musik terapi dan edukasi musik mengeksplorasi musik sebagai media untuk membuat individu menjadi lebih tenang, senang, dan segar. Dikatakan juga bahwa respon emosional terhadap konten musikal merupakan kunci untuk memicu motivasi musik yang bersifat intrinsik. Riset mengungkapkan bahwa individu yang mempunyai komitmen konsisten terhadap musik cenderung mempunyai pengalaman emosional dalam merespon konten musikal di masa awal pertumbuhan bila dibandingkan dengan mereka yang tidak pernah mengalaminya di masa awal pertumbuhan. Maka, konten musikal yang dialami secara emosional di awal masa perkembangan adalah kunci untuk menstimuli motivasi belajar.

Keempat, peluang untuk bisa berlatih secara penuh lewat dorongan motivasi yang sudah dimiliki. Terkait dengan motivasi belajar, diakui bahwa karakteristik individu (kemampuan pengendalian diri, tingkat kecemasan, serta gagasan dan kepercayaan) mempunyai peran yang sangat besar dalam membentuk cara seseorang melaksanakan sebuah tugas seperti misalnya belajar musik. Secara lebih spesifik, kesadaran diri mempunyai dampak pada perkembangan tujuan personal. Seseorang cenderung melakukan sesuatu jika sesuatu tersebut dianggap mempunyai nilai (value). Nilai ini targantung pada sejumlah jenis motivasi. Adapun jenis motivasi yang dimaksud ada empat. Pertama, ekstrinsik (ketika tugas dilakukan karena ada kemungkinan potensi reward yang bersifat eksternal seperti 'lulus ujian'). Kedua, sosial (ketiga tugas dilakukan untuk menyenangkan atau memuaskan orang lain). Ketiga, pencapaian (ketika tugas dilakukan untuk memuaskan ego, menjadi lebih dari yang lain). Keempat, intrinsik (ketika tugas dilakukan karena adanya ketertarikan dengan aktivitas tersebut, terkait dengan kenikmatan personal ketika melakukannya). Dari keempat jenis motivasi tersebut, motivasi intrinsiklah yang terbukti mampu menjadikan seseorang mempunyai komitmen dengan aktivitas tertentu, dalam hal ini musik, untuk jangka waktu yang lama.

Kelima, lingkungan dapat memunculkan sejumlah motivasi eksternal sebagai kunci membentuk kedewasaan. Manakala motivasi intrinsik ini terbentuk, pencapaian siswa akan lebih maksimal jika didukung oleh faktor sosial. Terkait dengan penguatan sosial dan pembelajaran, orangtua atau pengasuh dapat mempunyai peran yang penting dalam meningkatkan komitmen pembelajaran musik. Orangtua, dengan demikian perlu menetapkan perilaku tertentu terhadap musik. Selain

${ }^{1}$ Anthony Kemp, The Musical Temperament (Oxford: Oxford University Press, 1996), viii, 234-55 
orang tua, guru juga memiliki pengaruh yang besar dalam kesuksesan pembelajaran musik. Siswa dengan prestasi yang baik di bidang musik cenderung memiliki guru yang menghibur, bersahabat, selain juga sangat mumpuni dalam kemampuan bermusik. Sebaliknya, siswa dengan pencapaian rendah cenderung diajar oleh guru yang tidak bersahabat dan tidak kompeten. Seiring meningkatnya usia, kombinasi karakteristik guru untuk siswa dengan pencapaian rendah tidak berubah, sementara siswa dengan pencapaian tinggi mulai menyematkan aspek profesionalitas dan personalitas pada guru mereka. Dalam hal ini, kualitas profesionalitas seorang guru menjadi semakin menonjol. Dari sini terlihat betapa pentingnya aspek personalitas dalam mendukung aspek profesionalitas guru dalam mengajar, khususnya pada siswa usia muda agar bisa meningkatkan motivasi belajar mereka dan meningkatkan respon emosional terhadap aktivitas musikal. Setalah usia sebelas tahun, kebanyakan siswa tidak memerlukan motivasi eksternal dan mereka cenderung lebih mengambangkan hubungan intrinsik dengan instrumen yang mereka pelajari.

Lebih jauh, Hallam berpendapat bahwa fase awal yang kritis dalam memotivasi pembelajaran instrumen adalah pemilihan instrumen yang tepat. Pemilihan ini seringkali mempunyai stereotip dengan sex. Misalnya, anak perempuan cenderung memilih flute sementara anak laki-laki lebih menyukai drum. Lewat pemilihan instrumen yang tepat, latihan yang didukung orang tua, serta guru yang hangat dan bersahabat, tugas siswa kemudian adalah melatih kelima jenis ketrampilan musikal berikut ini. Pertama, ketrampilan membaca, memahami notasi, dan struktur (memungkinkan siswa untuk bisa melakukan primavista, mengingat musik, meningkatkan peta mental yang menghubungkan pengetahuan struktur dengan eksekusi musik). Kedua, ketrampilan aural (memungkinkan siswa dapat memproduksi intonasi dan kualitas tone yang baik, kemampuan untuk mengaplikasikan pengetahuan struktur musik dalam imrpovisasi). Ketiga, ketrampilan teknikal dan motorik (membangun struktur mental dalam rangka memahami musik perlu diperlukan untuk melatih tubuh meng-automatisasi proses nada yang dimainkan sehingga siswa dapat bermain secara fasih). Keempat, ketrampilan ekspresif (mengetahui bagaimana memanipulasi aturan struktural untuk menciptakan musik yang memiliki muatan emosional). Kelima, ketrampilan presentasi (belajar bagaimana untuk menampilkan aspek aural dan gestural dalam sebuah pertunjukan).

\section{Latihan yang efektif dan efisien dalam mempersiapkan pertunjukan}

Kelima jenis ketrampilan musikal yang disebutkaan Hallam di atas pada akhirnya akan dimanfaatkan musisi sebagai media untuk mempersiapkan sebuah performance yang ideal. Dalam mempersiapkan performance, musisi fokus pada dua hal: pertama, formulasi interpretasi dari karya musik, dan kedua, melatih aspek teknis dalam rangka merealisasikan interpretasi tersebut. Meskipun kedua hal ini berhubungan dekat, namun keduanya membutuhkan ketrampilan dan 
metode latihan yang berbeda. Sejalan dengan hal tersebut, John Sloboda mengatakan bahwa 'a performer might be a superb technician but lack musical insight, and vice versa'.

Bagaimana keahlian teknis dapat ditingkatkan? Victor Booth dalam bukunya We Piano Teacher mengemukakan bahwa selama proses latihan, 'conscious or voluntary acts become subconscious or involuntary'2. Dengan kata lain, aktivitas yang membutuhkan pemikiran sadar (analitis) dilatih hingga menjadi bawah sadar (otomatis). Menurut Paul Fitts dan Michael Posner, hal ini dapat dibagi ke dalam tiga tahapan: (1) tahap kognitif, yaitu fase awal yang masih membutuhkan fokus kesadaran secara penuh; (2) tahap asosiatif, dicirikan dengan adanya praktik perbaikan yang bertujuan mengeliminasi kesalahan; dan (3) tahap otonom, dimana teknis permainan tidak lagi membutuhkan fokus kesadaran karena sudah bersifat otomatis ${ }^{3}$. Pergerakan melalui ketiga tahapan tersebut bersifat gradual dari 'ingatan jangka pendek' (tahap 1 dan 2) ke 'ingatan jangka panjang' (tahap 3).

Metode utama yang dilakukan musisi agar bisa menuju tahap otonom adalah melalui aktivitas repetisi (pengulangan). Ingatan jangka pendek mempunyai kapasitas yang terbatas (umumnya hanya mampu menampung tujuh item) dan akan hilang kecuali ditransfer ke dalam ingatan jangka panjang. Keterbatasan ingatan jangka pendek akan berpengaruh terhadap kemampuan seseorang dalam melakukan tugas kompleks seperti mempelajari potongan musik. Pertama, agar praktik repetisi bisa berjalan efektif, maka tugas kompleks yang akan diproses oleh ingatan jangka pendek harus dipecah ke dalam unit yang lebih sederhana, yang oleh psikolog disebut 'chunking'. Dalam konteks musik, hal ini bisa dilihat ketika pemain melatih bagian kecil karya, lalu, ketika bagian tersebut sudah dikuasai, pemain beralih ke unit chunk yang lebih besar, dan seterusnya. Metode ini sangat direkomendasikan, salah satunya, oleh pianis Inggris James Ching. Ukuran chunk yang dipilih untuk latihan repetisi tergantung pada kompleksitas karya yang dimainkan dan kemampuan atau ketrampilan pemain. Linda Gruson mengatakan bahwa pianis profesional cenderung membagi chunk ke dalam unit yang lebih besar daripada pianis pemula. Kedua, melakukan latihan dalam tempo lambat. Dale Robert dalam Anxiety and Musical Performance mengatakan bahwa latihan dengan tempo lambat di awal fase latihan dapat membantu mengantisipasi kesalahan. Ketiga, konsentrasi. Konsentrasi adalah hal yang esensial dalam teknis latihan. Tidak hanya menjamin akurasi, namun juga untuk memaksimalkan efisiensi.

Tugas musisi berikutnya adalah memformulasikan interpretasi. Musisi harus menentukan bagaimana setiap nada akan dimainkan. Interpretasi musikal dikomunikasikan melalui parameter ekspresi seperti timing, dinamika, artikulasi, dan timbre (diantara parameter lainnya). Memang

\footnotetext{
${ }^{2}$ Victor Booth, We Piano Teachers (London: Hutchinson, [1946] 1971), 77.

${ }^{3}$ Paul M. Fitts and Michael I. Posner, Human Performance (Belmont, Calif: Brooks/Cole, 1967), 11-15.
} 
parameter ini tertulis pada score yang dimainkan. Namun demikian, petunjuk ekspresi yang tertera pada score cenderung bersifat lentur. Pemain masih mempunyai keleluasaan untuk menentukan, misalnya, seberapa kuat forte akan dimainkan, berapa lama fermata akan ditahan, atau seberapa cepat staccato akan dibunyikan. Interpretasi musikal, dengan demikian adalah proses yang sarat dengan subjektivitas. Stefan Reid menawarkan empat pendekatan yang dapat dilakukan oleh pemain untuk menguatkan formulasi interpretasi. Pertama, mendengarkan. Literatur pedagogis maupun psikologis mengatakan bahwa mendengarkan performance dari musisi lain adalah cara yang paling efektif untuk meningkatkan ketrampilan interpretasi. Sloboda mengatakan 'there is no satisfactory way of describing expressive variations in a way which allows one to incorporate them into one's own performance. Expressive techniques are passed from one musician to another by demonstration'4. Mendengarkan performance dalam hal ini tidak dimaksudkan untuk mengimitasi bentuk permainan dari musisi tertentu, melainkan untuk memperkaya khasanah perbendaharaan bunyi sehingga kita mempunyai banyak pilihan atau kemungkinan dalam memformulasikan interpretasi. Kedua, menyanyikan (bersenandung) ketika kita memainkan instrumen. Menyanyikan melodi dapat dipahami sebagai bentuk konstruksi mental yang menghubungkan not-not individu dari alur melodi menjadi 'sekwensi' ekspresi. Ketiga, mengumpulkan infomasi programatik yang bersifat ekstra musikal seperti cerita, deskripsi, atau sekwensi emosional. Hal ini memungkinkan pemain untuk memunculkan atau mengkonstruk narasi bunyi dari penggalan peristiwa musikal dari setiap bagian karya dalam konteks interpretasi secara menyeluruh. Keempat, interpretasi musikal dapat diformulasikan melalui analisis score (analisis tekstual). Quantz menyarankan perlunya pemain memahami analisis harmoni untuk kebutuhan ekspresi; semisal, disonan harus dibunyikan lebih dramatis daripada konsonan ${ }^{5}$.

Bagaimana hubungan antara keduanya? Antara teknik dan interpretasi? Negosiasi antara aspek interpretasi dan problematika teknik adalah permasalahan utama dalam dunia performance. Dalam hal ini, melalui risetnya, Wacinsky mengemukakan dua metode latihan yang berbeda ${ }^{6}$. Kelompok pertama cenderung membagi fase latihan ke dalam tiga tahapan: (1) berusaha mendapatkan gambaran umum tentang karya dan mengembangkan gagasan interpretative; (2) fokus pada tuntutan teknis dari karya yang dimainkan; dan (3) menggabungkan keduanya dan melakukan interpretasi ulang (mana yang mungkin mana yang tidak, terkait dengan batasan teknis yang ditemui). Kelompok yang kedua cenderung mengeliminasi ketiga fase tersebut dan melatih

\footnotetext{
4 John A. Sloboda, The Musical Mind: The Cognitive Psychology of Music (Oxford: Oxford University Press, 1985$), 90$.

${ }^{5}$ Johann Joachim Quantz, On Playing the Flute, $2^{\text {nd }}$ edn, trans. Edward R. Reilly (London: Faber and Faber, [1752] 1985$), 118$.

${ }^{6}$ A.A. Wicinski, 'Psichologiceskii analiz processa raboty pianist-ispolnitiela nad muzykalnym proizviedieniem [A psychological analysis of how the pianist-performer works on a musical composition]', Izviestia Akademii Piedagogiceskich Nauk Vyp, 25 (1950), 171-215, cited in Miklaszewski, 'Case study', 96.
} 
karya dari awal hingg akhir. Memunculkan gambaran umum tentang karya sebelum melakukan latihan secara detail memberikan dua keuntungan bagi musisi. Pertama, memberikan gambaran terkait perencanaan sesi latihan sehingga teknik yang dianggap sulit dapat 'diasingkan' di awal tahapan latihan dan menggarapnya kemudian. Kedua, pemain dapat memformulasikan gagasan interpretasi awal sebelum bersentuhan dengan latihan teknis sehingga aspek teknis akan dipandu oleh aspek interpretasi (teknik melayani musik, bukan sebaliknya). Cara interpretasi dimunculkan selama proses latihan berbeda dari satu pemain ke pemain lainnya. Hallam, dalam studinya, menemukan tiga pendekatan latihan yang berbeda terkait formulasi interpretasi dalam proses latihan: kelompok musisi yang pertama menggunakan analisis; kelompok lainnya menggunakan gabungan analisis dan intuisi; dan kelompok ketiga bekerja sepenuhnya pada aspek intuisi (mereka tidak secara sadar menghadirkan interpretasi selama latihan namun membiarkannya muncul dengan sendirinya selama proses latihan).

Kesimpulannya, latihan akan produktif manakala menyertakan kesadaran mental. Terlepas dari intensi untuk meningkatkan aspek teknis atau memformulasikan interpretasi, latihan akan efektif jika musisi mempunyai capaian goal yang jelas dan usaha dalam merealisasikannya. Dalam hal ini, latihan dapat dilihat sebagai aktivitas problem-solving dimana musisi mengidentifikasi masalah dan menentukan langkah untuk mengatasinya.

\section{Memaksimalkan kualitas performance}

Agar sebuah pertunjukan musik dapat ditampilkan secara maksimal, beberapa risalah menyarankan agar pemain berusaha mengingat karya yang dimainkan dan menyajikannya ke penonton dengan cara bermain dari ingatan (tidak membaca score). Aaron Williamon dalam risetnya menyimpulkan bahwa bermain dengan ingatan memberikan beberapa keuntungan sebagai berikut: (1) memungkinkan pemain untuk mendapatkan kebebasan ekspresi secara lebih besar, sekalipun kebebasan ini tidak bersifat absolut; (2) dapat lebih memunculkan hubungan psikologis yang bersifat langsung dengan penonton; (3) selama proses mengingat, pemain membutuhkan waktu latihan ekstra dan waktu yang dihabiskan selama proses mengingat ini secara tidak langsung juga meningkatkan penguasaan pemain terhadap repertoar yang dimainkan; dan (4), bagi penonton dengan latar belakang musikal yang baik, ketiga aspek di atas akan menambah kesan atau respon mereka kepada pemain, sehingga hubungan dua arah antara pemain dan penonton dapat terjalin lebih baik.

Adakah metode dalam mengingat musik? Edwin Hughes mengemukakan tiga jenis ingatan yang perlu diperhatikan musisi dalam mempersiapkan 'permainan dengan ingatan', yaitu: ingatan aural, visual, dan kinaestetik ${ }^{7}$. Ingatan aural (disebut juga ingatan auditori) memungkinkan individu

${ }^{7}$ Edwin Hughes, 'Musical memory in piano playing and piano study', Musical Quarterly, 1 (1915), 595. 
untuk mendengar komposisi dalam 'mind's ear', mengantisipasi bagian yang akan muncul dari score, dan membuat evaluasi segera dalam peristiwa pertunjukan. Ingatan visual berisi bayangan halaman score dan fitur pertunjukan lainnya yang 'berkesan' (mempunyai kesan di benak pemain) di dalam 'mind's eye'. Pemain piano misalnya, cenderung mengingat posisi tangan dan jari, struktur akor, dan pola pergerakan musik secara visual pada tuts yang dimainkan. Ingatan kinaestetik (yaitu otot jari atau tactile memory) memungkinkan pemain dapat mengeksekusi nada secara otomatis. Terkait tiga ingatan tersebut, Hughes dan Matthay menekankan bahwa tidak ada intelegensi memori yang sepenuhnya dapat terbentuk tanpa ada pengetahuan tentang harmoni, bentuk musik, dan struktur (untuk musik polifoni misalnya, pengetahuan tentang kontrapung dan kaidah fuga, misalnya $)^{8}$. Pengetahuan semacam ini, oleh beberapa pemain dan pedagog musik disebut dengan 'ingatan konseptual'9. Ingatan konseptual ini penting dalam memantabkan kepastian (to make sureness more sure) bagi pemain dalam melakukan eksekusi musik.

Susan Hallam mewawancara dua puluh musisi professional dan dua puluh lima musisi amatir. Hallam mengungkapkan bahwa musisi professional mengadopsi hal-hal sadar (strategi analitis) yang memungkinkannya mampu mengembangkan pemahaman tentang struktur musik yang dimainkan. Lebih jauh, terlepas musisi profesional atau amatir, Hallam menemukan bahwa strategi yang mereka terapkan dalam proses penggarapan karya seringkali tergantung pada jenis tuntutan teknis atau musikal dari karya yang dimainkan. Dalam riset serupa, Rita Aiello juga memeriksa metode yang dipakai musisi professional untuk mengingat musik. Dia menemukan beberapa tema. Pertama, musisi cenderung lebih menyandarkan pada ingatan aural daripada ingatan kinaestetik meskipun mereka sepakat dengan pentingnya ingatan kinaestetik (misalnya: penjarian). Kedua, semua musisi menekankan pentingnya bagi pemain untuk memiliki ide yang jelas tentang struktur musik dan analisis score adalah metode yang paling penting dan reliable untuk menguatkan aspek memorisasi. Ketiga, lima dari tujuh pianis mengatakan bahwa mereka mengingat dalam cara yang menyeluruh dengan membagi karya ke dalam potongan-potongan pendek dalam rangka untuk menghasilkan ingatan yang lebih solid dari keseluruhan karya. Keempat, pengetahuan improvisasi adalah asset yang penting untuk kebutuhan mengingat musik.

Riset yang dilakukan Hallam, Aiello, Hughes, dan Matthay berbicara tentang isu 'bermain dari ingatan'. Dapat disimpulkan bahwa investgasi tersebut mengungkap bahwa musisi cenderung menggunakan beragam metode untuk mengingat musik. Sayangnya, tidak satupun yang mengungkap mana metode (terkait ingatan aural, visual, dan kinaestetik) yang paling efektif. Yang paling bisa dijadikan pegangan dari keempat penelitian tersebut adalah musisi dengan standar

\footnotetext{
${ }^{8}$ Hughes, 'Musical memory', 598.

9 Ibid., 599
} 
ketrampilan yang tinggi cenderung menyandarkan pada metode analitis ketika berusaha untuk mengingat musik.

Prinsip 'expert memory' mencoba menjawab bagaimana individu dapat mengembangkan dan memelihara kemampuan luar biasa yang terkadang kita saksikan dimunculkan oleh musisi professional? Musisi dengan skil yang tinggi memiliki tuntutan yang sama (terkait dengan aspek memori) seperti praktisi lain di luar musik (atlit, misalnya). Dalam hal ini, setiap individu harus mengingat sekwensi gerakan dalam pertunjukan dan mengeksekusi gerakan tersebut dengan standar teknis tertentu. Karena ketrampilan teknikal dinilai berdasarkan bentuk-bentuk ideal, pemain harus membuat komparasi antara 'teknik aktual' dan 'teknik ideal' ketika perform. Dasar dari komparasi tersebut dimunculkan dari ingatan jangka panjang (long term memory) yang didapatkan dari hasil latihan bertahun-tahun.

Lewat komparasi tersebut, kita dapat mulai mengaplikasikan aspek teori yang ada pada ingatan musikal. Riset membuktikan bahwa kemampuan ingatan superior disokong oleh basis pengetahuan yang luas namun spesifik untuk kegiatan tertentu. Informasi pada basis pengetahuan ini selanjutnya dikumpulkan dan disimpan menjadi kelompok kelompok bermakna (chunk) yang seringkali diasosiasikan dengan aksi fisikal dan perintah tertentu. Contoh chunk dalam musik misalnya tangganada dan arpeggio. Musisi menghabiskan banyak waktu untuk melatihnya sehingga mereka dapat dengan mudah mengenalinya dan mampu mengeksekusinya dengan segera ketika proses primavista atau ketika bertujuan mengingat karya tertentu yang menyertakan teknik arpegio. Ketika database yang sangat besar dari pengetahuan yang bermakna tersebut telah diperoleh, individu dapat memanfaatkannya untuk menciptakan representasi mental dari informasi kompleks yang harus diingat. Singkatnya, representasi mental adalah sejenis peta internal yang dapat digunakan untuk mengingat hal yang spesifik.

Dalam hal musik, komposisi dapat direpresentasikan dalam hierarki mulai dari tingkat tertinggi pemahaman global (karya secara keseluruhan) hingga tingkat terendah (karya sebagai not individu). Batasan manusia dalam hal memproses informasi dan atensi, membuatnya tidak mungkin mengaktifkan seluruh representasi mental tersebut (aural, visual, kinaestetik) selama melakukan pertunjukan. Yang terjadi adalah, hanya sebagian saja yang diaktifkan pada satu waktu, dan wilayah aktif ini akan bergeser seiring laju permainan pemain dalam memainkan musik. Jelas sekali, ada potensi yang sangat besar bagi individu untuk memunculkan perbedaan dalam hal representasi konten musikal. Perbedaan tersebut dengan jelas dapat dilihat pada interview yang dilakukan Hallam dan Aiello. Namun demikian, representasi ini akan dapat dimanfaatkan dengan baik manakala terorganisir dan terus menerus dilatih secara ekstensif. Maka, salah satu metode yang 
efektif untuk mengorganisasi ingatan musik adalah dengan menggabungkan strategi analitis ke dalam praktik.

Contoh dari aplikasi gagasan tersebut dapat kita lihat pada cara Gabriela Imreh (pianis profesional) dalam membentuk representasi dari gerakan ketiga Italian Concerto karya Bach (riset ini dilakukan oleh Roger Chaffin dan Gabriela Imreh). Chaffin menemukan bahwa struktur formal komposisi berfungsi sebagai alat yang dengannya, Imreh mengorganisir representasinya. Imreh mengintegrasikan pengetahuannya tentang struktur formal pada tahap awal latihan dan kemudian mengandalkan sepenuhnya pada pengetahuan tersebut untuk memproduksi musik pada saat pertunjukan. Dia mengatakan bahwa ada tiga jenis sinyal: dasar, interpretatif, serta ekspresif, dan ia mengasosiasikannya ke dalam detail karya (not per not) melalui kombinasi ingatan aural, visual, dan kinaestetik. Yang termasuk sinyal dasar antara lain penjarian, kesulitan teknik dan kelompok not yang membentuk unit informasi yang dapat diiidentifikasi. Sinyal interpretatif antara lain frase, dinamika, tempo, dan pedaling. Sinyal ekspresif adalah semua hal di score musik yang coba diolah oleh pianis dalam hal ekspresi atau uansa musiknya.

\section{KESIMPULAN}

Standar kualitas pertunjukan yang dapat dikatakan ideal setidaknya melibatkan beberapa faktor. Pertama, lingkungan. Lingkungan mempengaruhi kualitas individu dalam lima aspek, yaitu memberikan stimuli awal musikal, membangun ikatan emosional antara anak dengan stimuli musikal di awal tahap perkembangan, memunculkan motivasi intrinsik sebagai bekal komitmen dalam proses pembelajaran musik, guru dan kurikulum untuk memfasilitasi proses belajar, dan lingkungan eksternal (guru dan orang tua) sebagai faktor penunjang.

Kedua, strategi latihan. Strategi latihan yang efektif dan efisien harus membedakan dua tugas utama musisi, yaitu latihan teknik dan interpretasi. Latihan teknik dilakukan secara repetitif. Agar repetisi ini dapat dilatih secara maksimal, maka unit musikal sebaiknya dipecah menjadi unit-unit yang lebih sederhaha (chunking), dilatih dalam tempo lambat, dan latihan dengan konsentrasi. Untuk bisa memformulasikan interpretasi musikal dengan baik, musisi sebaiknya: (1) banyak mendengar khasanah pertunjukan (rekaman atau langsung) dari musisi lain dalam rangka untuk memperkaya perbendaharaan bunyi; (2) menyanyikan frase (untuk musik instrumental) ketika menggarap repertoar untuk membangun representasi mental dari karya yang dimainkan; (3) menelusuri informasi programatik dari karya yang dimainkan (sejarah, gaya, intensi komposer); dan (4) melakukan analisis intrinsik terkait struktur musik yang dimainkan.

Ketiga, manakala proses latihan sudah dapat dilakukan secara efektif dan efisien, maka tugas berikutnya adalah memaksimalkan kualitas pertunjukan dengan cara mengingat repertoar. Bermain 
dengan ingatan memberikan beberapa keuntungan: pemain lebih dimungkinkan memiliki kebebasan ekspresi walaupun, dapat memunculkan hubungan psikologis langsung dengan penonton, dapat meningkatkan penguasaan pemain atas karya yang dimainkan, dan penonton yang memiliki latar belakang musik akan lebih dalam memberikan respon/apresiasi sehingga dapat memunculkan hubungan dua arah antara pemain dan penonton.

\section{DAFTAR PUSTAKA}

Bernstein, S. (1981). With Your Own Two Hands: Self-Discovery through Music. New York: Schirmer.

Davidson, J. (2002). Communicating with the body in performance. In J. Rink, Musical

Performance, A Guide to Understanding (pp. 144-152). New York: Cambridge University

Press.

Davidson, J. (2002). Developing the ability to perform. In J. Rink, Musical Performance, A

Guide to Understanding (pp. 89-101). New York: Cambridge University Press.

Evans, A. (1994). The Secrets of Musical Confidence. London: Thorson.

Hallam, S. (1998). Instrumental Teaching: A Practical Guide to Better Teaching and Learnig. Oxford: Heinemann.

Hargreaves, D. J. (1986). The Developmental Psychology of Music. Cambridge: Cambridge University Press.

Kemp, A. (1996). The Musical Temperament. Oxford: Oxford University Press.

Mattthay, T. (1926). On Memoriaing and Playing from Memory and On the Laws of Practice Generally. London: Oxford University Press.

Reid, S. (2002). Preparing for Performance. In J. Rink, Musical Performance, A Guide to Understandingg (pp. 102-112). New York: Cambridge University Press.

Reubart, D. (1985). Anxiety and Musical Performance: On Playing the Piano from Memory. New York: Da Capo Press.

Roger Chaffin, G. I. (2002). Practice Perfection: Memory and Piano Performance. Mahwah NJ: Erlbaum.

Sloboda, J. A. (1985). The Musical Mind: The Cognitive Psichology of Music. Oxford: Oxford University Press.

William, A. (2002). Memorising Music. In J. Rink, Musical Performance, A Guide to Unserstanding (pp. 113-126). New York: Cambridge University Press. 